\title{
The future of hydrocarbons: Hubbert's peak or a plateau?
}

Eric S. Cheney, Department of Earth and Space Sciences, Box 351310, University of Washington, Seattle, Washington 981951310, USA; vaalbara@u.washington.edu

Marianne W. Hawkes, 2164 Shadow Brook Court, Carson City, Nevada 89703-7370, USA; ophirmill@yahoo.com

\section{INTRODUCTION}

Due to economics, science, technology, and the increased manufacturing of hydrocarbons from sources other than oil, the world's production of oil and gas in the twenty-first century will not peak sharply but will plateau or gradually decline. The scenario presented here places us among the optimists.

Data used in this paper come mostly from the Web sites of the U.S. Energy Information Administration and the National Energy Board of Canada and from pre-1977 publications of the former U.S. Bureau of Mines.

Oil is measured in barrels containing 42 U.S. gallons. The heat value of $6000 \mathrm{ft}^{3}$ of gas is approximately equivalent to a barrel of oil, so gas is expressed as barrels of oil equivalent (boe). Table 1 uses billions of barrels, Gb, and Gboe.

\section{HISTORY}

The concept that resources are essentially finite may have originated with Thomas Malthus. He concluded in 1798 that the exponential growth of Earth's human population was unsustainable because agricultural production could only increase arithmetically. Since then, mechanized farming, irrigation, refrigeration, chemical fertilizers (from petroleum and other mineral deposits), hybrid grains, genetic modification, and improved transportation systems have blossomed. Now, famine is only caused by political events and by the inability to deliver emergency supplies following natural disasters.

The concept of the inelasticity of oil resources stems from Hubbert's (1956) prediction, based on declining rates of discovery, that the annual production of oil in the 48 contiguous United States would crest in 1970, which it did, at $3.5 \mathrm{~Gb}$. Hubbert's analysis excluded Alaska and the Gulf of Mexico, where oil was discovered in the 1960s and later. Because the contiguous United States is the most explored area in the world and because the worldwide rate of discovery has declined in the past decade, "Hubbert's Peak" is a common model for the world's future production (Deffeyes, 2001). "Peak oil" posits that production will fall as sharply in the twenty-first century as it rose in the twentieth. If so, the economic and political consequences are potentially dire (Urstadt, 2006).

World oil and gas currently have annual production growth rates of $1.9 \%$ and $2.3 \%$, respectively. Predicting exhaustion is

doi: 10.1130/GSAT01706GW.1 not as simple as dividing present reserves by projected production. Estimates of ultimately recoverable oil and gas are qualitative; uncertainties include future prices, geologic models for undiscovered deposits, and future technology. Production is also driven by demand, but significantly higher prices might decrease demand and, hence, affect production.

\section{ECONOMICS}

Higher prices stimulate exploration and production, including from deposits that previously were uneconomic. However, during Hubbert's time (from the 1930s until after 1970) the price of oil was effectively fixed by the Texas Railroad Commission at $\leq \mathrm{US} \$ 3 /$ barrel, and after 1938, the U.S. Federal Power Commission fixed the interstate price of natural gas at $\leq \mathrm{US} \$ 0.90 / \mathrm{kft}^{3}$. The resultant decline of the price of oil in uninflated dollars discouraged exploration, which is documented by a decline in the number of wells drilled, from a high of 57,111 in 1956 to 25,851 wells in 1972 . The record was 91,553 wells in 1981, but $<25,000$ wells were drilled annually from 1992 to 1999, and 33,831 were completed in 2004.

Conventional oil and gas flow from wells. Primary recovery by pumping is typically $20 \%-30 \%$ of the oil present. Secondary recovery can produce the same amount again by injecting gas (including $\mathrm{CO}_{2}$ ), steam, fire, or detergents into reservoir rocks. Higher prices for oil permit more secondary recovery plus the production of oils that are so viscous that primary recovery is minimal.

Higher prices now justify the huge capital investments required for liquefied natural gas (LNG) and gas to liquids (GTL). Intercontinental trade of LNG via cryogenic ships is rapidly expanding. GTL will replace diesel with cleaner fuels. One reason natural gas is in demand is that it generates less $\mathrm{CO}_{2}$ than oil and only $\sim 40 \%$ of the $\mathrm{CO}_{2}$ from coal of equal heat value. Natural gas was relatively unimportant in Hubbert's time (Table 1) and crested in the United States in 1973 at 3.6 Gboe.

TABLE 1. SELECTED GAS AND OIL STATISTICS FOR THE WORLD AND THE UNITED STATES

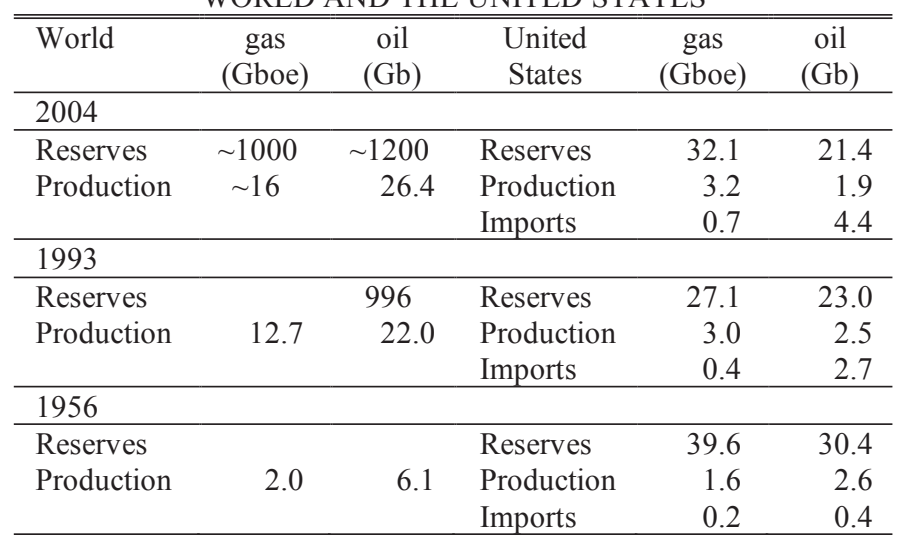


Increased production of natural gas will extend conventional production.

Sufficiently higher prices also encourage conservation, which can affect production. Conservation includes smaller and more fuel-efficient cars (including hybrid engines), urban mass-transit systems, energy-efficient (green) buildings, cogeneration of electricity, wearing sweaters indoors, etc.

\section{GEOSCIENCE}

The application of plate tectonics came after 1970, providing the rationale for deep-water drilling on the margins of continents and fostering a better knowledge of other tectonic environments. Additionally, our understanding of petroliferous rocks has changed appreciably as a result of sequence stratigraphy and other geological and geochemical advances.

\section{TECHNOLOGY}

Significant technological advances in finding and producing oil occurred after Hubbert's prediction. These include seismic reflection surveying (especially 3-D seismic imaging), deepwater (off-shore) drilling and production, and horizontal drilling (now up to $10 \mathrm{~km}$ ).

\section{SUBSTITUTION}

Other forms of energy, non-conventional oil and gas, and conservation will increasingly substitute for conventional oil and gas. Ethanol from biomass (sugar cane, switchgrass, etc.) produces more energy than it consumes in the full cycle of fertilizing, growing, harvesting, transportation, and manufacturing, but much ethanol from corn does not. On a volume basis, ethanol is $\sim 2 / 3$ as efficient a fuel as gasoline.

In 2004 , about $21 \%$ of the electricity in the United States was generated by $0.3 \mathrm{~Gb}$ oil and 1.1 Gboe gas; coal generated $49.8 \%$. The amount of electricity produced by coal, nuclear power, and renewable sources will increase if the relative prices of oil and gas increase.

Canada's oil reserves (now second in the world) experienced a quantum leap in 2005 when the U.S. Securities and Exchange Commission reclassified the tar sands of Alberta as oil. Mining and refining recover $81 \%$ to $90 \%$ of the oil in the sand as synthetic oil. In 2004, mining and refining complexes were profitable at about US\$30/barrel; the spot price for future oil has exceeded US\$50/barrel since early 2005. Annual production from mines and wells in 2003 was 0.18 Gb; it will be $0.7 \mathrm{~Gb}$ by 2015. In 2004, the mineable reserves of Alberta tar sands, $35 \mathrm{~Gb}$, were greater than the United States' reserves of conventional oil (Table 1).

Another nonconventional source of oil is coal, which the United States has in abundance. Germany, during WWII, and South Africa, during the apartheid era, manufactured synthetic oil by reacting coal with water at high temperatures. Most strategies for future "clean coal" envision a similar process, in which pollutants, including $\mathrm{CO}_{2}$, will be sequestered, and cogenerated steam will produce electricity.

With continued high prices, in-place gasification and/or liquefaction of deep coal or tar sands could be economic. With even higher prices, oil shale and methane ice (clathrates) in sediments on the sea floor might be exploitable. Of course, if such schemes consume more energy than they produce, they are unlikely to be worthwhile.

\section{THE NEAR FUTURE}

In the next few years, world oil production may outstrip demand because of projects planned before the current price increases. To maintain prices, the Organization of the Petroleum Exporting Countries (OPEC) is now considering decreasing production.

Nationally owned companies currently control $90 \%$ of the world's production of oil and gas. These companies tend to be secretive and under-capitalized. The major private oil companies have been through boom and bust before. Accordingly, they are focusing on projects that are viable at US\$25 to US\$35/ barrel, reducing debt, increasing dividends, and repurchasing their stock. Meanwhile, they fret that too few areas will remain politically attractive for exploration and production.

\section{CONCLUSIONS}

Table 1 and Deffeyes (2001, p. 3) show that U.S. oil production in 2004 was about twice what Hubbert projected (mostly because of production in Alaska and the Gulf of Mexico). Van der Veen (2006) noted that by 2004 cumulative U.S. oil production (exclusive of Alaska and the Gulf of Mexico) totaled 161 $\mathrm{Gb}$ and that Hubbert had predicted the ultimately recoverable amount would be 170 Gb. 2004 reserves, exclusive of Alaska and the Gulf of Mexico, were 13 Gb.

Economics, conservation, substitution, future advances in geoscience and technology, and concerns about global warming imply that the world's combined production of conventional and nonconventional oil and gas will not peak sharply but will plateau or decline gradually in the twenty-first century. The world's per capita production of conventional oil and gas will, of course, decline more steeply.

As for gasoline, it will not run out soon, but it will become progressively more expensive. Presumably, some will always be available at US\$20 to US\$100 (in 2006 dollars) per 3.8 liters, even if it comes from tar sands, cellulose, coal, or oil shale.

Static or gradually declining production would be fairly easy to manage if oil and politics did not mix. Crises will recur due to aggressive or unstable exporting nations and to counterproductive legislation and foreign policies of some of the major consuming nations.

\section{ACKNOWLEDGMENTS}

We thank A.E. Howard, L.A. Gilmour, D.S. Cowan, B.J. Skinner, and P.M. Cook for very helpful reviews.

\section{REFERENCES CITED}

Deffeyes, K.S., 2001, Hubbert's Peak, The Impending World Oil Shortage: New Jersey, Princeton University Press, 208 p.

Hubbert, M.K., 1956, Nuclear energy and the fossil fuels: Drilling and Production Practice, Proceedings of American Petroleum Institute Spring Meeting, p. 725.

Urstadt, B., 2006, Imagine there's no oil: Scenes from a liberal apocalypse: Harper's, v. 313 , no. 1875, p. $31-38,40$.

van der Veen, C.J., 2006, Reevaluating Hubbert's prediction of U.S. peak oil: Eos (Transactions, American Geophysical Union), v. 87, no. 20, p. 199, 203, doi: 10.1029/2006EO200003.

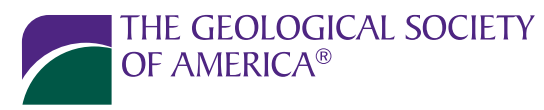

